Grand Valley State University

ScholarWorks@GVSU

\title{
War Neurosis versus Savings Psychosis: Working-Class Politics and Psychological Trauma in Weimar Germany
}

Jason Crouthamel

Grand Valley State University, crouthaj@gvsu.edu

Follow this and additional works at: https://scholarworks.gvsu.edu/hst_articles

Part of the History Commons

\section{ScholarWorks Citation}

Crouthamel, Jason, "War Neurosis versus Savings Psychosis: Working-Class Politics and Psychological Trauma in Weimar Germany" (2002). Peer Reviewed Articles. 1.

https://scholarworks.gvsu.edu/hst_articles/1

This Article is brought to you for free and open access by the History Department at ScholarWorks@GVSU. It has been accepted for inclusion in Peer Reviewed Articles by an authorized administrator of ScholarWorks@GVSU. For more information, please contact scholarworks@gvsu.edu. 
Jason Crouthamel

\section{War Neurosis versus Savings Psychosis: Working-class Politics and Psychological Trauma in Weimar Germany}

Like other social and political issues in Weimar Germany, traumatic neurosis was a hotly-contested area of debate between different groups devastated by the first world war. In recent studies of the effects of the war on European society, historians have examined the social and political biases, especially with regard to gender and class, that shaped how doctors diagnosed and defined mental trauma in modern warfare. ${ }^{1}$ This article will offer a way of looking at the war neurosis debate in Germany 'from below'. This can be done by examining the responses of psychologically-disabled war victims to the psychiatric profession's arguments on the nature of war neurosis and the memory of the war. ${ }^{2}$ Working-class victims of psychological trauma used the war neurosis debate to define the psychological impact of the war on different social classes in Weimar Germany. War-disabled interest groups on the political left adopted the voices of war victims to argue that the middle classes, through psychiatrists and state welfare administrators, systematically sought to erase the traumatic effects of the war in an attempt to deny responsibility for its human costs or, at worst, deliberately to prepare Germany for another world conflict. In the responses of psychologically-disabled war victims to the state and psychiatrists, we find a battle over the act of forgetting, as organized working-class veterans and their representatives criticized the repression of the traumatic war experience and theorized on the lingering neuroses that crippled

1 See Paul Lerner, 'Psychiatry and Casualties of War in Germany, 1914-1918', Journal of Contemporary History, 35, 1 (January 2000), 13-28; Doris Kaufmann, 'Science as Cultural Practice: Psychiatry in the First World War and Weimar Germany', Journal of Contemporary History, 34, 1 (January 1999), 125-44. For research on male hysteria and British psychiatrists' assumptions about social class, see Elaine Showalter, 'Rivers and Sassoon: The Inscriptions of Male Gender Anxieties' in Margaret Randolph Higonnet, Jane Jenson et al. (eds), Behind the Lines: Gender and the Two World Wars (New Haven, CT 1987), 61-9.

2 On the experiences of both physically- and psychologically-disabled veterans in Kaiserreich and Weimar Germany, particularly in terms of social and economic re-integration, see Robert Weldon Whalen, Bitter Wounds - German Victims of the Great War, 1914-1939 (Ithaca, NY 1984); Bernd Ulrich, ' . . . als wenn nichts geschehen wäre', in Gerhard Hirschfeld, Gerd Krumeich and Irana Renz (eds), "Keiner füblt sich hier mehr als Mensch" - Erlebnis und Wirkung des Ersten Weltkriegs (Frankfurt am Main 1986), 140-56; for veterans' writings on the psychological stress caused by the war, see Bernd Ulrich, Die Augenzengen - Deutsche Feldpostbriefe in Kriegsund Nachkriegszeit, 1914-1933 (Essen 1997), 191-226. 
interwar society. The most damaging neuroses, these war victims and their political advocates argued, originated during the postwar period with the refusal of the traumatized middle classes to come to terms with defeat, and not with the refusal of working-class soldiers to fight in the trenches.

After defeat and revolution, military and state-employed psychiatrists claimed that the psychological collapse of 'hysterical' soldiers, particularly those from the working classes, played a major role in precipitating Germany's national crisis. Psychiatrists integrated this argument into their version of the stab-in-the-back legend, claiming that healthy men kept their nerve during Germany's moment of crisis in the summer of 1918, while inherently weak soldiers, influenced by leftist political organizations, lost their will and nerve just when Germany was on the brink of victory, making them more psychologically susceptible to an alleged leftist betrayal of psychologically intact, loyal front soldiers. The psychiatric establishment increasingly allied itself with conservatives, arguing that war neurotics were malingerers and national enemies who weakened Germany's capacity to revitalize the nation. ${ }^{3}$ Psychiatrists labelled working-class men as particularly prone to 'hysterical' breakdown, due to their lack of self-control and, as doctors argued, less developed emotional capacities for coping with the stress of combat. Doctors characterized the psychological traumas experienced by men from workingclass backgrounds as inherent in their social class, rather than as actual wounds experienced at the front. ${ }^{4}$

In the 1920s, the two largest parties on Weimar's political left, the Social Democratic Party (SPD) and the Communist Party (KPD) argued vehemently that psychological trauma was a legitimate wound and that the working classes were the most traumatized of the war's survivors. However, these organizations were reluctant to admit that men in their ranks were neurotic. The Social Democratic war victims' association argued at first that war neurosis was a universal experience that afflicted working-class and middle-class war victims stressed by total war. After losing parliamentary battles for pensions, however, they later developed a more narrow definition of warinduced psychological illness. SPD officials theorized that the middle classes, in their zeal to cut pensions and save the budget, were more neurotic than war victims and less willing than traumatized working-class men and women to heal the social-psychological consequences of the war. Bourgeois interest groups, SPD representatives bitterly concluded by the late 1920 s, were all too

3 Psychiatrists' conflation of mental illness and the rise of leftist political agitation at the end of the war is well documented by Paul Lerner in Hysterical Men: War, Neurosis and German Mental Medicine, 1914-1921 (Dissertation, Columbia University 1996), 364-5.

4 See, for example, Paul Plaut, 'Psychographie des Kriegers' in Beiträge zur Psychologie des Krieges (Leipzig 1920), 110-18. For comparison with Britain, see Joanna Bourke's fascinating work Dismembering the Male - Male Bodies, Britain and the Great War (Chicago 1996), 111-12. Bourke shows how in Britain, officers suffering from shell shock were diagnosed with 'anxiety neurosis', while enlisted men were labelled 'hysterics'. 
willing to forget psychologically disabled veterans, and disabled veterans in general, as unwanted reminders of Germany's lost war. ${ }^{5}$

Communist representatives of war victims took this a step further. They argued that psychiatrists, in league with middle-class conservative interest groups, deliberately repressed the traumatic psychological effects of the war in order to soothe the national memory and prepare Germany for another world war. According to communist war victims' representatives, psychologicallydisabled working-class men who sought pensions for mental disabilities were not 'hysterics' as doctors claimed. The 'pensions psychosis' that doctors claimed infected the social welfare system with overly-dependent men, activists claimed, was really a construction of the middle classes who sought to cover up their pathological, neurotic failure to pay for the human costs of the war.

The Reichsbund der Kriegsbeschädigten, Kriegsteilnehmer und Hinterbliebenen, an organ of the Social Democratic Party, was Weimar's largest war victims' organization with over 600,000 members in $1921 .{ }^{6}$ The Reichsbund advocated war neurotics' rights to the same financial assistance and health care awarded to physically-disabled veterans. Under the 1920 National Pension Law, these rights were guaranteed to psychologically-disabled veterans who were diagnosed with directly war-related mental wounds, which qualified them as 'severely disabled'. ' However, Weimar's Labour Ministry, which administered the re-integration of war victims into postwar society, gradually cut pensions and health care to psychologically-disabled veterans on the basis of state-hired psychiatrists' evaluations. The Labour Ministry's doctors argued that many of these men failed to recover because of their lack of will and 'neurotic' dependence on the welfare state. The alleged war-related wounds, doctors claimed, actually stemmed from inherent psychopathological disorders which were not caused by their wartime service, thus disqualifying these veterans from receiving disability pensions. ${ }^{8}$ With assistance from the Social Democratic Party, psychologically-disabled war victims argued that their wounds were indeed legitimate and that they could become constructive

5 See Bourke, op. cit., for further comparisons to Britain. In Britain, mentally-disabled veterans were also seen as deviant and shameful after the war. In Germany, this sentiment was intensified by the lost war and, as I will argue here, the war neurosis question was increasingly politicized by groups seeking to assign blame for defeat.

6 Whalen, op. cit., 128.

7 Franz Schweyer, Ministerialdirektor im Reichsarbeitsministerium, Die Ansprüche der Kriegsbeschädigten und Kriegerhinterbliebenen nach dem neuen Reichsversorgungsgesetze (Berlin 1920).

8 In postwar debates, state psychiatrists disagreed on the degree to which mental wounds appeared in men who were psychologically healthy before the war. This was a crucial question for the Labour Ministry, as only those with directly-related war wounds qualified for pensions. See, for example, P. Lißmann, Die Wirkungen des Krieges auf das männlichen Geschlechtsleben (München 1919), 28. 
members of society if they were granted the same access to occupational therapy and financial assistance as other veterans.

Social Democratic leaders asserted that psychological trauma bridged the experience of combat and home fronts, as the public, regardless of class and gender, would identify with psychologically-stressed veterans in ways that they could not relate to amputees and gas victims, thus building a shared consciousness between men and women, veterans and civilians, traumatized by war and economic crisis. Social Democrats who played a key role in creating the National Pension Law of 1920 insisted that the nation widely supported compensation for mentally-disabled veterans because civilians, also stressed by the depravations of total war, could relate to their wounds. One former military officer, Dr Beyer, who later became an SPD representative in the Prussian State Assembly, argued that the majority of doctors working for the Labour Ministry, who continued to cut pensions for psychologically-disabled veterans, did not act according to public sentiment, but rather were still beholden to military thinking and budget considerations. While men from working-class backgrounds were still categorized as 'hysterics' and 'shirkers', Beyer complained, former officers were diagnosed with 'organic nervous disorders' and given easier paths to pensions. Psychologically-traumatized men, Beyer insisted, should be fully integrated into postwar society regardless of social background, as fully-fledged war victims, to be given the same occupational training, health care and war victims' status as severely disabled veterans. ${ }^{9}$

In the early years of the republic, the SPD's war victims' organization became the most active defender of mentally-disabled veterans' rights. On 30 November 1918, Karl Tiedt, who in February 1919 would break away from the Social Democrats to join the Communist Party, sent a Reichsbund resolution to the new Chancellor, Friedrich Ebert. Tiedt demanded that the war-disabled be given better treatment than they received under the wartime government, including an increase in pensions, the creation of state programmes for occupational re-training that gave greater choices to the war-disabled, and unlimited, free health care for war victims and their dependants. ${ }^{10}$ At their meetings on overhauling the welfare system, social democrats often singled out the psychologically injured, who were imprisoned for shirking service at the front as foremost symbols of the Imperial government's oppression of war victims: 'The treatment of war wounded under duress, namely those suffering from nervous disorders . . . is to be immediately suspended.' The Secretary of the Ministry of the Interior met with workers' council representatives authorized by the Social

9 Bundesarchiv (hereafter BA) Berlin. Reichsarbeitsministerium (hereafter RAM). R3901/Film 36206. Verfassungsgebende Preußische Landesversammlung, Förmliche Anfrage der Abgeordneten Dr Beyer (Westpreußen) und Genossen, 28 March 1919. As a former military doctor, Beyer was exceptional in his political views. Observing the treatment of war neurotics in field hospitals, he concluded that men were treated unjustly compared to officers.

10 BA Berlin. RAM. R3901/Film 36072. 'Eingaben und Anträge allgemeinen Inhalts in Sachsen der Kriegsbeschädigtenfürsorge und Kriegswohlfahrtspflege.' Reichsbund letter to Ebert, signed by Tiedt, 30 November 1918 . 
Democratic Party to negotiate the release of mentally-ill veterans from prisons and asylums. ${ }^{11}$ Reichsbund officials also came to the defence of homeless, psychologically-disabled veterans just returning from the front. The police posted warnings about the 'Schüttler' ('shakers') and 'Zitterer' ('quiverers') on Berlin street corners and subway stations, describing them as 'notorious beggars' pretending to suffer from the tremours and tics that plagued authentic war neurotics. ${ }^{12}$ Reichsbund leaders blamed the press for wrongly conflating war neurotics and malingerers who avoided work. ${ }^{13}$

The public's negative perception of war neurotics had long since been shaped by psychiatrists who had first worked as military doctors and then were employed by the Weimar Labour Ministry. Frustrated at the failure of psychologically-traumatized war victims to heal after the violence of the trenches, doctors regularly singled out this group of war victims as welfaredependent 'pension neurotics', chronic 'psychopaths' and social deviants who did anything to avoid work. ${ }^{14}$ Reichsbund officials complained to the Labour Ministry that state doctor (Regierungsrat) Wolfskehl in Frankfurt am Main was degrading all psychologically-wounded veterans when he described one as a 'psychopath who does not value work'. ${ }^{15}$ Reichsbund activists accused doctors of being 'pension squeezers' whose first priority was budget-cutting. Rather than objectively evaluate the conditions of mentally-ill veterans, Reichsbund officials argued, doctors regularly exaggerated the ability of these men to work and recover their health in order to save the state money and curry favour with labour ministers. ${ }^{16}$

In the new Republic's expanded but according to war victims insensitive, over-bureaucratized medical system, activists argued that doctors neglected the subtle but myriad psychological traumas caused by the war. ${ }^{17}$ In one case,

11 BA Berlin. RAM. 3901/Film 36072. 'Eingaben und Anträge allgemeinen Inhalts in Sachsen der Kriegsbeschädigtenfürsorge und Kriegswohlfahrtspflege.' Reichsbund regional branch Hanau a.M. letter to workers' and soldiers' councils, 10 December 1918.

12 BA Berlin. RAM. 39011/Film 36137. 'Spenden für Kriegsbeschädigten und Hinterbliebenen, Allgemeines'. Polizeipräsident Richter to the Interior Ministry, Berlin, 24 July 1922. See also newspaper clippings in this file, including 'Eine Massenepidemie geheilt', Deutsche Tageszeitung, December 1919 (day of issue not given in file).

13 BA Berlin. RAM. R3901/Film 36137. 'Spenden für Kriegsbechädigten und Hinterbliebenen, Allgemeines.' Letter from Reichsbund to Labour Ministry, 3 January 1921.

14 For further background on pension neurosis, see Lerner, op. cit., 382-411. See also George L. Mosse, 'Shell Shock as a Social Disease', Journal of Contemporary History, 35, 1 (January 2000), 101-8.

15 BA Berlin. RAM. R3901/Film 36027. 'Beschwerden Beschädigten über Begutachtung und Gutachter.' Letter from Reichsbund to Labour Ministry concerning medical examinations at Versorgungsamt Frankfurt a.M., 13 April 1927.

16 BA Berlin. RAM. R3901/Film 36027. Letter from Reichsbund to Labour Ministry, 7 February 1923.

17 Over-bureaucratization as a source of failure for Weimar's welfare system has been analysed by, among others, Detlev Peukert, The Weimar Republic - The Crisis of Classical Modernity, trans. Richard Deveson (New York 1989), 130-40; David Crew, 'The Ambiguities of Modernity: Welfare and the German State from Weimar to Hitler' in Geoff Eley (ed.), Society, Culture and the State in Germany, 1870-1930 (Ann Arbor, MI 1996), 319-45. 
the brother of Mathias Scherer, a veteran diagnosed with war-related nervous disorders that caused stress to his heart, asked the Reichsbund to punish the 'criminal' doctors for their incompetence. Scherer had died only a few weeks after the doctor accused him of faking his symptoms. The Reichsbund asked that the Labour Ministry lead a public enquiry into the case, and asserted that Scherer would not have died if doctors were more sensitive to the complex psychological and nervous disorders experienced by veterans. ${ }^{18}$

The state's doctors, Reichsbund officials proclaimed, were prejudiced against more than just war neurotics. Their scientific objectivity was also compromised by their biases against men who belonged to the Social Democratic Party, which, state-employed psychiatrists argued, sapped men of their independence and will to recover psychologically from the war. ${ }^{19}$ In 1924 , Reichsbund representatives from the Barmen district investigated state doctor Burckhardt, who allegedly refused to implement orders from the health care courts to provide occupational therapy for psychologically-disabled patients with ties to the social democratic Reichsbund. Burckhardt reportedly informed war victim Hartmann Schmoll, who suffered from psychological trauma, lung problems and a leg wound, that his wounds were not as bad as he, the Reichsbund and health insurance officials - all 'lay persons' - claimed. Schmoll recounted his encounter with Dr Burckhardt to the Reichsbund:

As I stepped into the examination room, I was received by the physician Dr Burckhardt with the following words: 'So how old are you?' 40 years I answered. With that I received the reply: 'What do you, a man of 40 years, still want to be examined for?' He asked further: 'Do you belong to any association, perhaps the Reichsbund?' I replied that I was a member of the Reichsbund. Then the doctor retorted: 'Why are you in the Reichsbund? Certainly you are a man and can represent yourself. ${ }^{20}$

Reichsbund representative Hölter investigated Burckhardt and found the doctor's diagnoses to be convoluted and 'unscientific', shaped by his assumption that nervous veterans were socially deviant. After observing one of the doctor's interactions with a patient, Hölter recorded:

Yesterday someone was diagnosed here with a $100 \%$ nervous disorder. Now just because

18 BA Berlin. RAM. R3901/Film 36028. 'Beschwerden Beschädigten über Begutachtung und Gutachter.' Letter from Reichsbund to Labour Ministry, 23 June 1927.

19 See, for example, Medizinalrat Gustav Kolb, Direktor der Heil und Pflegeanstalt Erlangen, Die nervös Kriegsbeschädigten vor Gericht und Strafvollzug - Nach einem Vortrag für Richter, Ärzte und Strafanstaltsbeamte (München 1919), 34-7. Dr Kolb was a former director of several field hospitals that specialized in war neurosis. He was hired in 1919 by the Ministry of Justice and the Interior Ministry to give judges, lawyers and others in the judicial system a set of guidelines for distinguishing psychologically-disabled soldiers from men whose mental disorders were not related to wartime service. Kolb argued that the Social Democratic-led republic did not provide men with the essential values of work, national duty and respect for law and property. Instead, he argued, the republic rejected the authority of doctors and encouraged men to dwell on their injuries rather than recover.

20 BA Berlin. RAM. R3901/Film 36027. Letter from Hartmann Schmoll, included in Reichsbund report, sent to the Labour Ministry, 21 October 1924. 
this man wears sandals and flowered stockings does not make him neurotic. When I asked Dr Burckhardt whether one could judge the man's character based on his footwear, he said: 'This man got married after the war and he has two children. He is not really neurotic. There is no woman who would marry a man who is so sick. ${ }^{21}$

In his report, Hölter asserted that the state had no authority in administering the war victim's question as long as Labour ministers employed such prejudiced doctors, and he demanded that Burckhardt be dismissed. With advice from the health insurance and pensions office (Hauptversorgungsamt) in Coblenz, however, the Labour Ministry decided that evidence gathered by Reichsbund officials pertained to individual complaints that had to do with personality conflicts, not with professional competence or the systematic oppression of mentally-disabled patients organized in the social democratic war victims' association..$^{22}$

In their letters to the state, psychologically-disabled veterans on the left claimed that they were victims of continuing trauma inflicted by the Labour Ministry's doctors who denied the reality of mental injuries. ${ }^{23}$ These men complained that their treatment in the social welfare system often replicated the psychological violence they had experienced at the front. Veteran August Fischer claimed that state medical representative Dr Schulz at the Hannover disabled veterans' Nervenstation made him undress, paraded him through the hospital to embarrass him and then accused him of simulating his mental injuries. Fischer wrote that he felt 'raped' by the state:

Against this type of treatment I submit this firm protest and I will not fail to speak out against this above-described rape of a disabled veteran .... If this gentleman [Dr Schulz] had come back from the front sick, or if he had spilled his blood for the fatherland, he would certainly not treat a disabled war veteran like a repulsive dog or deny him a means to exist .... There can be no doubt that after this critique of the state-doctor's medical evaluation, my observations will be so embarrassing to the state that it will be rejected, the doctor's examination will be considered justified, reason will be denied and Terror will govern. ${ }^{24}$

Using extremist rhetoric to portray the war-disabled as embattled victims against an irrational, authoritarian state, Fischer saw continuity between the

21 BA Berlin. RAM. R3901/Film 36027. Report from Reichsbund member Hölter, Barmen district, delivered to Labour Ministry, 26 September 1924.

22 BA Berlin. RAM. R3901/Film 36027. Letter from Reichsbund to Labour Ministry, 12 November 1924. See also report from Hauptversorgungsamt Coblenz to Labour Ministry, 5 December 1924.

23 The notion of a second trauma is used by late twentieth-century psychiatrists to describe the experience of trauma survivors, including victims of rape, incest and AIDS, who encounter rejection and stigmatization in their pre-trauma environments from groups that would ideally help facilitate healing. On Vietnam veterans who encounter secondary trauma through rejection from family and community, see Jonathan Shay, Achilles in Vietnam (New York 1994), 195-209. For an interesting study of survivors' experiences with cultural reactions to trauma, see Marian Mesrobian MacCurdy, 'Truth, Trauma and Justice in Gilion Slovo's Every Secret Thing', Literature and Medicine, 19, 1 (Spring 2000), 115-32.

24 BA Berlin. RAM. R3901/Film 36027. August Fischer letter to Labour Ministry, 26 October 1921. 
horrors of the trenches and systematic state 'terror' that he believed characterized Weimar's welfare state. Fischer's fears were echoed in letters from diagnosed war neurotic Alex Elshoffer. In a letter that displayed mangled reasoning and a stream of evidence that is difficult to follow, Elshoffer claimed that he was being persecuted by health care administrators and doctors, whom he called 'crows who picked out the eyes of their patients' ${ }^{25}$ Men diagnosed with war neurosis characterized themselves as uniquely persecuted, which they argued entitled them to be leaders of the war-disabled in the continuing war against doctors. Karl Unger, first diagnosed with war neurosis in 1917, claimed in a letter to the Reichsbund that he was physically attacked by a psychiatrist, Dr Gessler, at the University of Heidelberg in 1924. Unger characterized his fellow patients as weak and submissive after they encouraged him to surrender to Dr Gessler for fear of retribution in the form of unfavourable pension evaluations. ${ }^{26}$ Writing to President von Hindenburg in 1925, Unger said he was no 'whiner', but a 'loyal subject' for whom 'dire emergency and unjust treatment of my pension forces me to take this step'. Unger proceeded to explain that he and other psychologically-disabled veterans had no choice but to fight back against doctors who did not respect a veteran 'who gave my entire savings to war loans and sacrificed my health and happiness for the fatherland'. ${ }^{27}$ Unger portrayed himself as a heroic fighter working on behalf of his disabled, spiritually broken comrades, reluctant to cause problems but left with no choice when faced with the state's unsympathetic doctors.

In the Reichsbund, civilian victims of psychological stress shared status with combat veterans as traumatized war victims. Women leaders in the Social Democratic Party argued that men were not the only psychological victims of the war, and thus not exclusively entitled to fight against doctors and their narrow definitions of war victimhood. An expanded definition of psychological trauma caused by war played a key role in this debate over who was entitled to status as psychologically-disabled war victims. Women Reichsbund members argued that war neurosis was an all-inclusive wound that linked combat veterans and those on the home front. In the mid-1920s, Social Democratic leaders favoured these broad definitions of 'war victim' and 'trauma' that encompassed not only front soldiers, but also those on the home front who were psychologically strained by the human losses of the war and the stresses caused by economic crisis. This was part of their aim to build a collective consciousness based on the idea that the interests of wounded veterans and civilians were the same..$^{28}$

25 BA Berlin. RAM. R3901/Film 36027. Alex Elshoffer letter to Labour Ministry, 11 August 1921.

26 BA Berlin. RAM. R3901/Film 36028. Karl Unger letter to the Reichsbund, Ortsgruppe Karlsruhe, copy sent to Labour Ministry, 18 October 1924.

27 BA Berlin. RAM. R3901/Film 36028. Karl Unger letter to President von Hindenburg, 22 June 1926.

28 H. Hoffmann, 'Psychologie und Kriegsopfer', Reichsbund - Organ des Reichsbundes der Kriegsbeschädigten, Kriegsteilnehmer und Kriegerhinterbliebenen, 1 July 1926. 
In the mid-1920s, women activists argued that working-class women, like trench survivors, were unable to shed the haunting memories of the war, resulting in symptoms of neurosis comparable to those found in victims of combat trauma. ${ }^{29}$ Traumatic memories, these activists argued, were intensified by the unbearable stress of work and providing for severely disabled husbands. When the popular press reported on a woman who killed herself and her four children in 1926, Reichsbund leaders blamed her act on the psychological strain of taking care of her mutilated, invalid husband and children while working as the sole bread-winner. ${ }^{30}$ In unresolved national debates over the creation of a National Day of Mourning, the Reichsbund strongly advocated the incorporation of psychologically-traumatized civilians, particularly women, into the memory of the war. In her Reichsbund editorial, 'Viewpoints of those left behind [Hinterbliebenen] regarding the National Day of Mourning', Alma Hißfeld argued that in the official memory of the war, the republic should recognize 'the many physical and psychological sufferings of dependents, whose privations and stresses lead to daily crisis and anxiety'. ${ }^{31}$ Women thus advocated expanding the definitions of trauma to incorporate the war and postwar period, and to include women traumatized by poverty.

In an effort to come to terms with the war's lasting effects on women, Reichsbund member Martha Harnoß detailed the psychological strains of war and its aftermath that destroyed the psychological health of non-combatants. Though their experiences were different, Harnoß noted, women suffered as much as men from the psychological stress of war:

For dependants, heart ailments and tuberculosis are the consequences of psychological agitation and the economic conditions of the war and postwar period. Even today nobody admits, either in the government or among affluent citizens, that most women sacrificed the best of their health for the fatherland in their stressful work to earn a living. As many of us women just learned, those under the burden of becoming workers and at the same time having to do housework, collapse. How often have we seen children become complete orphans because their mothers were over-stressed? How often do we still find today that we can barely mention wartime and the psychological suffering with the loss of breadwinners and the economic consequences of the postwar period, without one of the survivors suffering a nervous breakdown? This is the sad picture of the effects of the war on the health of women. ${ }^{32}$

Harnoß thus equated women's experiences with those of the war-disabled, defining psychological trauma caused by overwork as part of the collective sacrifices made for the nation. Similar to the war-disabled, Harnoß argued,

29 On the social and psychological impact of the war on working-class women, see Ute Daniel, trans. Margaret Ries, The War from Within - German Working-Class Women in the First World War (Oxford 1997), 231-72; Ute Frevert, trans. Stuart McKinnon-Evans, Women in German History — From Bourgeois Liberation to Sexual Liberation (Oxford 1989), 149-204.

30 'Zwei feindliche Welten', Reichsbund, 1 May 1926.

31 Alma Hißfeld, 'Stellungsnahme der Hinterbliebenen zum nationalen Trauertag', Reichsbund, 1 April 1921.

32 Martha Harnoß, 'Zur Heilbehandlung der Kriegerhinterbliebenen', Reichsbund, 1 May 1926. 
women were denied adequate social assistance from the state and the 'affluent' who were unwilling to recognize the consequences of the war for working men and women. In these tracts on psychological traumas experienced by workingclass women, women activists pushed Reichsbund leaders to recognize the particular traumas of working-class versus middle-class civilians, thus challenging the organization's assumption that psychological trauma was a universal, unifying wound. ${ }^{33}$

Though the Social Democratic leadership would not theorize on the different neuroses experienced by middle- and working-class Germans until the late 1920s, they did prescribe particular roles for women in leading postwar recovery. Reichsbund leader H. Hoffmann argued that women gained most from the sense of community provided by Social Democratic politics. Women, he argued, were well-suited to leading veterans and civilians out of the most universal psychological consequence of the war - 'war victimhood'. In both combat victims and civilians, Hoffmann argued, there existed a deepseated 'inferiority complex' and loss of faith in the value of one's work that lay behind Germany's postwar crisis. Many groups, he argued, felt a repressed hostility towards the state and society, leaving them victimized, isolated and helpless in their struggle to adjust to postwar conditions. ${ }^{34}$ Mentally traumatized women, because they were excluded from the state's definition of war victims, Hoffmann argued, discovered early on that the Social Democratic community provided an alternative basis for overcoming psychological despair:

The Reichsbund has in the course of its existence returned to many of its members the self-trust lost in shell holes and in economic crisis. Our mourning women comrades found diversion and psychological resurgence in the activities of the organization . . . which has given each member the chance to heal their inferiority complexes ... by renewing their sense of the joy of life [Lebensfreude $].^{3.5}$

The party, Hoffmann claimed, affirmed war victims' sense of self-worth by legitimizing the complex psychological stresses inflicted by war and its aftermath and providing work that had social value. For both men and women still haunted by a shattering loss of meaning, Reichsbund officials assured them that 'in the service of the organization one awakens consciousness of one's

33 'Waisenrente nach dem 18. Lebensjahr', Reichsbund, no. 7, Juli 1926. Reichsbund leaders pushed legislation through the Reichstag that reflected their view that war neurosis was not limited to the combat front. The SPD took credit in 1924 for adding an amendment to the 1920 National Pension Law, paragraph 41, guaranteeing pensions to veterans' orphans over 18 who were still unable to take care of themselves due to mental or physical illness.

34 H. Hoffmann, 'Psychologie und Kriegsopfer', Reichsbund, 1 July 1926. Hoffmann found psychoanalytic theory useful in understanding war neurosis. He employed terms like 'repression' and 'inferiority complex' to describe the myriad psychological problems that affected Reichsbund constituents beyond the trenches, and he alluded to the disruption of sexual relations between traumatized veterans and their wives as one factor leading to postwar neuroses.

35 Ibid. 
own productivity again'.$^{36}$ Social democracy, he insisted, did not encourage welfare dependency as doctors argued, but was rather a catalyst for motivating war victims to work by rebuilding self-esteem and giving them a sense of social inclusion.

In the wake of the 1923 inflation, the recovery of one's self-esteem proved to be of little consequence in the fight for pensions, as state ministers looked to cut war victims who did not show quantifiable progress in their ability to hold a job. With the encouragement of conservative Reichstag representatives from nationalist parties seeking to trim the social welfare budget, finance ministers complained that of the 3.4 billion marks in the national budget, 31.2 per cent went to war-disabled pensions. ${ }^{37}$ In the 1926 Reichstag hearings on overhauling the pension system, finance ministers concluded that it was doubtful that psychologically-disabled veterans who had still not healed almost ten years after the war were actually suffering from directly war-related wounds, the basis for a veterans' disability pension, and that they should thus be cut from state support and placed in family care. The National Committee on War Victims, an advisory committee for the Reichstag, began hearings in December 1926 at which psychiatrists gave medical testimony that justified the elimination of pensions for war neurotics, especially those with symptoms of delayed psychological problems that appeared years after the war. Psychiatrists testified that those men who were diagnosed with war-related psychological trauma during or just after the war but who had not yet healed were either hereditarily ill or 'pension psychotics' who had become dependent on welfare, or both, and thus did not deserve war-disabled pensions..$^{38}$

Social Democrats in the Reichstag who initially defended war neurotics as legitimate war-disabled, including those whose psychological wounds persisted or appeared late after the war, now began to cave in to the Labour Ministry's psychiatrists. Social Democratic Party leader Erich Roßmann admitted that not all psychological problems among veterans could be proved to be directly war-related. At the Reichstag hearings, he concluded that 'it is doubtful that many of these cases are in fact war-related. It is in the hands of state administrative authorities as to what counts for a doubtful case and what does not. ${ }^{39}$ Roßmann recognized the state's doctors as the ultimate authority in defining war neurosis, and he acknowledged that only men with psychological trauma that could be traced directly to an event in the trenches deserved a disability pension. Party leaders immediately instructed their war victims' organization, the Reichsbund, to reassure psychologically-disabled veterans who would lose their pensions that the SPD-sponsored Unemployment

36 'Im Dienst der Organization erwacht wieder das Bewußtsein eigener Leistungsfähigkeit', Reichsbund, 1 July 1926.

37 Whalen, op. cit., 157-8.

38 BA Berlin. RAM. R3901/Film 36252. 'Geisteskrankheiten und Dienstbeschädigungen' from Dr Scholze's Reichstag hearing of 2 December 1926.

39 Ibid. 
Insurance Law was on the verge of passing through parliament, and that this would fill the gap left by lost pension income. ${ }^{40}$

With cuts in pensions for diagnosed war neurotics now re-evaluated as nonwar victims, psychologically-disabled veterans' letters flooded the Labour Ministry and the Reichsbund. War neurotics who described themselves as once loyal to the republic and its social democratic ideals accused the state and the SPD of betraying veterans and the memory of their sacrifice by cutting social welfare for traumatized front soldiers. Konrad Drucklieb, an iconoclastic former bank clerk, diagnosed war neurotic and Social Democratic supporter of the republic, was fired from his job as a taxi-driver in 1929 for 'mental instability' after a collision that resulted in a passenger's death. When he attempted to renew his war victims' pension, Drucklieb found that his pension office no longer accepted doctors' wartime or early 1920s diagnosis that his psychological wounds were directly war-related. The Labour Ministry held to a 1929 psychiatric evaluation that Drucklieb was still able to earn a living, as long as he did not drive a taxi. ${ }^{41}$

Drucklieb wrote letters to the state in which he accused Social Democrats of conspiring with conservatives to 'starve psychologically disabled veterans' in order to serve their own political interests. ${ }^{42} \mathrm{He}$ argued that he deserved more than just the thanks of the fatherland for serving in the war, but also respect from the existing republic, which he claimed he helped to save from the counter-revolutionary Kapp Putsch shortly after the war:

The war, which I volunteered for as an 18-year-old, disabled me so that I could not maintain my secure career. It is also worth mentioning that I continued to serve after 1919 and volunteered to take up weapons during the Kapp Putsch in order to save the young republic! That doesn't count at all any more - I've been abandoned: the thanks of the republic is the clear reflection of 'the thanks of the fatherland', which is as familiar to us as the 'Amen' in church! A front fighter might as well hang himself - it is as they say: All Quiet on the Western Front ['Im Westen Nichts Neues' - the title of Remarque's famous work]. ${ }^{43}$

Drucklieb equated what he believed was the republic's betrayal of psychologically-disabled veterans with the Kaiserreich's betrayal, often sarcastically quoted by the war-disabled: 'The thanks of the fatherland will certainly be yours!' Drucklieb predicted that the war-disabled would give their 'thanks' to the Social Democrats and conservative ministers by throwing support behind Hitler: 'You egoists on ministry sofas mock us and throw us into the most bitter crisis. ... But think about the day when Hitler could perhaps be offered

40 See Ludwig Preller's Sozialpolitik in der Weimarer Republik (Stuttgart 1949), 363-5. Preller argues that unemployment insurance legislation was the Social Democratic Party's priority during the 1925-27 period.

41 BA Berlin. RAM. R3901/Film 37011. 'Einzelne Problemen'. Hauptversorgungsamt Brandenburg-Pommern letter to Labour Ministry, 5 March 1930.

42 BA Berlin. RAM. R3901/Film 37011. Drucklieb letter to Labour Ministry, 23 March 1932.

43 BA Berlin. RAM. R3901/Film 37011. Drucklieb letter to Labour Ministry, 9 June 1929. 
a chance! The support of the people is always changing - the thanks of the fatherland will certainly be yours. ${ }^{44}$

Drucklieb argued that the state victimized his family as well. In his applications for a psychological disability pension, Drucklieb mentioned that his wife was seeking psychiatric treatment for the stresses caused by her husband's economic troubles. ${ }^{45} \mathrm{He}$ did not consider her wounds and status comparable to his own, but referred to her to illustrate the crushing effects of pension cuts on his family. His wife's nerves were dependent on his own, he claimed, and she would recover if the state restored his pension. Drucklieb built his case around his own war experience: 'The collapse of my nerves was singularly caused by the war and its terrifying stresses, its deprivations ... the crashing artillery fire which gave me a glance into death. ${ }^{46}$ His lengthy appeals to the National Pension Courts were not successful. Psychiatrists concluded that Drucklieb possessed a 'psychopathic constitution' with symptoms that included 'severe irritability, delusional whininess, and depression'. ${ }^{47}$

Although the Labour Ministry did not comment directly on the condition of Drucklieb's wife, she had a greater chance of winning welfare assistance for her psychological problems than her husband. Drucklieb was granted a onetime $150 \mathrm{RM}$ emergency relief payment, which covered rent and food for two months, after his wife visited a psychiatrist who reported that she was unable to earn a living, thus leaving the family with no wage-earner. ${ }^{48}$ Women received support for psychological breakdowns primarily because doctors did not doubt the authenticity of their 'hysterical' symptoms, not because, as Reichsbund activists had long argued, they suffered trauma comparable to war neurosis. Subsequently, women who experienced nervous breakdowns while caring for their injured husbands and impoverished families regularly found assistance from the state with the help of Reichsbund representatives. For example, the Labour Ministry determined that Frau Johanna Bachmann, widow of a soldier who suffered from war-related psychological problems that led to his death in 1924, experienced her own 'severe nervous breakdown' and

44 BA Berlin. RAM. R3901/Film 37011. Drucklieb letter to Labour Ministry, 23 March 1932. A political chameleon, Drucklieb indicated in subsequent letters that Hitler's aim to make wardisabled the 'first citizens' of the Third Reich was appealing, but carried no substance in terms of pension reform. This proved true, as war-disabled received a medal and a 60-mark single payment in 1934, but the 1920 National Pension Law was not significantly revised as promised. On first world war veterans in nazi Germany, see James M. Diehl, The Thanks of the Fatherland (Chapel Hill, NC 1993), 31-53.

45 BA Berlin. RAM. R3901/Film 37011. Drucklieb to Labour Ministry, 8 September 1930.

46 BA Berlin. RAM. R3901/Film 37011. Drucklieb to Labour Ministry, 21 July 1921.

47 BA Berlin. RAM. R3901/Film 37011. Drucklieb to Labour Ministry, 9 October 1931. This description of his psychological condition is quoted by Drucklieb himself, who began to sign his letters with self-mocking sarcasm: 'Drucklieb, severely disabled, pensioner, and whiner'.

48 BA Berlin. RAM. R3901/Film 37011. His wife's status as unable to earn a living was summarized by Drucklieb in his 8 September 1930 letter. Her condition is not elaborated on in a letter from the Berlin pension office to the Labour Ministry when they were granted emergency assistance. 
symptoms of 'hysteria' in 1926 that prevented her from holding down a job. After a brief medical review, psychiatrists approved an additional 200-mark single emergency welfare payment in addition to her widow's pension. ${ }^{49}$ While men were expected to have overcome their traumatic memories nearly ten years after the war, the state recognized that postwar social and economic crises caused psychological strain that legitimately prevented women from earning a living. Labour ministers were determined to remove from the welfare system war neurotics who had not healed, labelling them as over-dependent, unmanly fakers. The SPD failed to protect these individuals from conservatives, but Reichsbund leaders could at least claim partial victory, as women traumatized by postwar social and economic crises found compensation from the state for their psychological stress.

From the beginning of the Great Depression, the Labour Ministry continuously cut war victims' relief in general, until the pension budget was reduced by one-third. In 1930, Erich Roßmann declared that a war existed over pensions: 'Social reactionary forces have launched a total offensive against the pension system. In parliament, we are engaged at present in a kind of pension trench war. ${ }^{50}$ Reichsbund leaders employed a popularized psychiatric discourse to explain the psychological origins behind budget cuts. The medical profession, state bureaucracy and popular media, Reichsbund activists argued, were all dominated by bourgeois interest groups who repressed their own distinct war neuroses. Reichsbund members speculated that Germany's unwillingness to confront the traumatic psychological consequences of the war was a particular middle-class neurosis. One member attacked the 'weak-nerved bourgeois public' that could not stomach the 'many individual tragedies buried beneath stories of finance reform and Reichstag debates'. ${ }^{51}$ He wrote:

Such reports of tragedies that befall war-wounded cause anxiety and disturbance; but the normal middle-class citizen does not want to be disturbed and shocked. He just wants to 'take a break' (Feierabend) when he reads the newspaper. Calm, calm and more calm. His nerves are indeed so weak. ${ }^{52}$

Reichsbund leaders also published articles on 'savings psychosis' (Sparpsychose), a form of mental illness that allegedly affected only middle-class Germans. 'Savings psychosis', Social Democrats noted, could be seen in Labour Ministry officials who were 'obsessive' and 'neurotic' in their zeal to cut the budget for war victims' pensions and evade responsibility for the human costs of the war. ${ }^{53}$ Social Democratic war victims' advocates thus

49 BA Berlin. RAM. R3901/Film 36139. 'Sammlungen in Auslände, Einzelfälle, Allgemeines.' Letter from Reichsbund to Labour Ministry, 28 January 1926. Labour Ministry letter dated 3 February 1926 confirms payment to Frau Bachmann.

50 Whalen, op. cit., 169-70. Quoted from Erich Rossmann, 'Die Entwicklung der parlamentarischen Lage für die Kriegsopfer seit dem Hamburger Bundestag', Reichsbund, 25 May 1930.

51 'Die Liquidierung der inneren Kriegslasten', Reichsbund, 25 January 1930.

52 Ibid.

53 'Sparpsychose', Reichsbund, 25 February 1930. 
assured each other that while the middle classes repressed their traumatic memories, the nerves of the working classes, led by the Social Democratic Party, were strong enough to confront the deep psychological effects of the war. This dichotomy between working-class and middle-class nerves, however, had already been distinguished by the SPD's rival for workers' votes.

In contrast to the Social Democrats, the Internationaler Bund, an arm of the Communist Party that claimed 100,000 members at its peak, did not make the war neurosis question a central feature of its strategies for defending what representatives perceived as the interrelated interests of working-class wardisabled and victims of social and economic oppression. Only after the 192627 cuts in war-disabled pensions did the war neurosis question draw serious attention from Internationaler Bund leaders. After these cuts, Bund activists treated the war neurosis question as primary evidence of the systematic material and psychological oppression of disabled veterans and workers. For leaders of the Internationaler Bund, the denial of pensions to psychologicallytraumatized veterans proved that the class war and the revolutionary struggle had a fundamentally psychological dimension. Communist officials portrayed the war neurosis question as the most compelling evidence that the middle classes sought to erase the traumatic memory of the war in order to ensure the nation's psychological readiness for another conflict that exploited the proletariat for capitalist gain. Bund officials controlled their party's opposition on war neurosis by addressing the issue later than the SPD, and by placing party ideologues, rather than traumatized war victims themselves, in charge of defining the psychological legacy of the war.

Communist Party leaders argued that psychiatrists spearheaded the systematic elimination of traumatic memory from the national consciousness. Psychiatrists, KPD officials concluded, were frauds who covered up the real traumatic legacy of the trenches:

It is this Prof. Neuhaus in Berlin who concluded that a war victim who has several bullets in his skull was healthy and able to work. To him, all others are hysterics. In explaining war hysteria, it is the new method to say that these illnesses already existed in their youth and thus have nothing to do with the war, or that they occurred after the war and are symptoms of age. The war and its consequences are thus supposed to be struck from the consciousness of the people, so that they will agree to new imperialist goals of the German bourgeoisie against Soviet Russia. ${ }^{54}$

Bund leaders portrayed psychiatrists as primary agents in concealing the real horrors of the trench experience by falsely labelling its victims, especially those from the working classes, as 'hysterics'. Psychiatrists, KPD officials claimed, tried to control the memory of the war by promoting it as a strengthening

54 'Kongreß der Werktätigen - Referat des Genossen Dr Klauber', Internationaler Bund Organ der Kriegsbeschädigten, Kriegsteilnehmer und Kriegerhinterbliebenen (later changed to Organ des Internationalen Bundes der Opfer des Kriegs und der Arbeit), no. 3 (February 1927). 
experience that separated the psychologically strong-willed from the weak, and in particular, the hysterical proletariat from the steel-nerved officers. ${ }^{55}$

The Bund defended its constituents against doctors' arguments that psychologically-disabled war victims lacked the necessary 'calm, manly character' that distinguished legitimate war victims from hysterics. ${ }^{56}$ Bund representatives suggested that some of their working-class comrades may indeed have been psychologically unable to withstand trench warfare. However, it was not in the context of capitalist state-sanctioned warfare that men proved themselves, they insisted. Only by joining the communist war victims' organization and the proletarian revolution, KPD leaders argued, did working-class war victims 'assert their strength as men, which had been stripped by a state that turned them into dependent beggars' ${ }^{57}$ The militant revolutionary movement was the primary agent for regenerating traits that the state's psychiatrists argued were lacking in these veterans, including a sense of self-control, and the will to work. In an essay titled 'War Hysteria', one columnist called upon psychologically-disabled veterans to find healing in active class struggle and revolution. He wrote: 'You war victims must take control of health care with greater energy, and you must learn through this control that only one world power is capable of healing the wounds of the capitalist war of exploitation: the power of the revolutionary proletariat. ${ }^{58}$ The psychological regeneration of traumatized veterans, according to Bund ideologues, began with the invigorating experience of class struggle, which helped men to take control over their own health and productivity.

Those war victims who continued to depend on the capitalist state for their recovery, party officials argued, surrendered their self-control to a neurotic, disturbed medical and welfare system. The capitalist state, they claimed, turned working-class war victims into passive, helpless welfare dependants and stigmatized them with the label 'hysteric'. ${ }^{99}$ Terms like 'hysteric' and 'pension neurotic', officials noted, could only be applied by doctors and professors who had no idea what it was like to lose one's mental health in war or in the struggle to find work..$^{60}$ Bund leaders insisted that the state's doctors, not the working-class veterans who bore the brunt of the war, were hysterics and psychopaths. In the most direct, caustic terms, Bund leaders encouraged constituents to accuse doctors of projecting their own disorders onto their

55 On the different constructions of the memory of the war, particularly the myth of the war experience as constructed by the right, see George L. Mosse, Fallen Soldiers - Reshaping the Memory of the World Wars (New York 1990). Competing debates over the memory of the war among different social groups are examined by Richard Bessel, Germany after the First World War (Oxford 1993), 254-84. For a cultural history on mourning and the memory of the war, see Jay Winter, Sites of Memory, Sites of Mourning - The Great War in European Cultural History (Cambridge 1995).

56 'Der Wert der ärztlicher Gutachten', Internationaler Bund, no. 9 (September 1926).

57 'Kriegs-Hysterie', Internationaler Bund, no. 12 (December 1925).

58 Ibid.

59 Ibid.

60 'Renten Neurose', Internationaler Bund, no. 8 (August 1928). 
patients: 'Do not tolerate the proctologists who belittle you and your hardearned rights. Assert that there is no judgment handed to you that is not really the sickness of your doctor himself. ${ }^{61}$ The Bund offered advice on achieving control over one's psychological health: rather than suffer humiliation under 'a businessman disguised as a doctor', war victims should find a 'neutral, trustworthy doctor' who was not attached to the state health-care system, and consequently not corrupted by capitalist interests. ${ }^{62}$

The medical director at Berlin's main welfare office complained to the Labour Ministry that the Bund's sensationalist news articles 'incited and influenced war-disabled', and contributed to worsening, tense relations between doctors and patients. ${ }^{63}$ As part of their campaign, communist activists mailed their October 1928 issue, containing the banner headline 'Psychiatry and Neurology in the Service of the Capitalist Class', to the Berlin welfare office. In this article, Bund member Emil Vogeley argued that 'pension psychosis' and 'hysteria' actually originated in the middle-class psyche. Vogeley theorized that pension psychosis was really just a construction of the middle classes used to justify their own status and argue that the working classes were lazy and irresponsible. He concluded: 'The theory of pension psychosis is rooted in the social structure of a class-based society.' Behind the theory of pension psychosis, Vogeley wrote, affluent Germans tried to hide 'a much more dangerous psychosis - the class-struggle psychosis':

Like all other class-struggle organizations, [the Bund] suffers from the 'delusional psychosis' that the class-based society is collapsing and wants to end once and for all the exploitation of one class by another. What a terrible delusion! It provokes all powers of resistance in $\mathrm{Dr}$ Rosenfeld. He can do nothing against this delusion but fight, because he himself suffers from a psychosis, the class-struggle psychosis of the middle classes, from which he originates and which he must protect! ${ }^{64}$

According to Vogeley, the middle classes' efforts to defend their status and interests had reached a crisis point in mental degeneration. The theory of class struggle, he observed, was no 'delusion', as bourgeois interest groups claimed. Instead, Vogeley argued, it could be seen in the 'psychotic' behaviour of doctors in their exploitation of disabled veterans.

The science of psychiatry, according to Bund representatives, was not objective, but just another weapon in the class struggle. Bund activists argued that psychiatrists were actually projecting onto the proletariat their own psychological breakdown in the wake of collapsing capitalism. Vogeley concluded his essay with the following observations on the symptoms of middle-class neuroses that manifested themselves in the psychiatric establishment:

61 Ibid.

62 'Geschäftsmann oder Arzt!', Internationaler Bund, no. 3 (March 1928).

63 BA Berlin. RAM. R3901/Film 36029, 'Beschwerden.' Letter from the medical director at the Berlin main pension office (signature illegible) to the Labour Ministry, 19 November 1928.

64 Emil Vogeley, 'Die Psychiatrie und Neurologie im Dienst der kapitalistischen Klasse', Internationaler Bund, no. 10 (October 1928). 
We live in the age of decay, corrosion, and degeneration of capitalism. Under the pressure of the historically rising class, the proletariat, the middle classes rear their instincts towards selfpreservation, and their life-instinct falls into desperation. The feverish delirium with which the middle classes try to preserve themselves truly reflects their psychological life. This delirium is expressed in the specialized bourgeois sciences . . . and in the unprecedented cynicism with which their representatives in the sciences more or less conspicuously place themselves in the services of the capitalist class with their requirements, deductions, conclusions and application of scientific ideas. ${ }^{65}$

Using terms like 'instincts', 'self-preservation' and 'delirium' to diagnose the middle classes' psychotic defence of capitalism, Bund representatives appropriated existing medical discourse. Employing this framework, they argued that the middle-class psychological victims of the class war were Germany's most dangerous neurotics, as they held the power to repress their allegedly psychotic tendencies while at the same time preserving the socio-economic system that produced their neurosis.

In labelling the middle classes as the deepest neurotics, communist leaders questioned the boundaries that separated mentally-ill war victims from their health-care providers. Long before war victims' representatives picked up this argument, however, war victims from various points on the political left had been criticizing health-care providers as the true neurotics in the doctorpatient relationship. This was a popular theme in antiwar literature that emerged in the 1920s. The Association of Pacifist War Veterans and Friends of Peace argued that the 'psychosis' that spurred the middle classes to lead Germany into war in 1914 lived on in the form of doctors repressing the voices of mentally-disabled war victims. In their first pamphlet, 'War Fury Visions of a Wounded Soldier', Hans Schlottau observed in his short story about a mentally-ill veteran that trauma was an enlightening, though tortuous experience, as it triggered a revaluation of values and insight into the 'propaganda of hate' that dominated the war effort. In contrast, doctors who tried to return these men to the trenches were really the insane, as evidenced by their efforts to convince men that they were morally obligated to commit murder. ${ }^{66}$

The inversion of mentally-ill war victims and doctors sometimes took on a more literal twist on the front lines in the welfare offices. At a 1921 Berlin city assembly meeting, witnesses testified that a psychologically-disabled war victim under the pseudonym 'Dr Franzke-Rudolph' used false papers to disguise himself as a medical doctor in order to infiltrate his pension and health-care office. Once established in the administration area of the welfare office, this individual began to 'incite rebellion' and, according to the police, attempted to set up a 'communist headquarters' for the revolution led by welfare recipients. Local papers reported that in his clash with police just before

65 Ibid.

66 Hans Schlottau, 'Kriegsfurioso — Visionen eines Verwundeten.' Erste Flugschrift, Friedensbund der Kriegsteilnehmer und Friedensfreunde. Vorwort, Hermann Klamfoth (Hamburg 1920). The alleged insanity of doctors often appeared in anti-war literature. See, for example, Karl Kraus' Die letzten Tage der Menschheit, in which psychiatrists are portrayed as sado-masochists who enjoy administering electro-shock treatment to shirkers identified by insane officers. 
he was led off to an asylum, the would-be doctor declared that the health-care administrators, insurance court clerks and doctors were all 'mentally ill' and he called for a new system led by war victims themselves. ${ }^{67}$

In mid-1920s tracts on the war neurosis question, communist leaders urged their constituents diagnosed with war neurosis to take control of their recovery from doctors and, like the enthusiastic individual mentioned above, join the KPD in revolution. Until the success of the planned revolution, however, Bund leaders seemed to have little use for war neurotics in roles other than those of martyrs and victims. Particularly after the onslaught of the Great Depression and the deepest pension cuts, mentally-ill veterans appeared in the Bund's sensationalistic articles as anonymous, helpless figures to be pitied. In a 1932 feature story, 'The Thanks of the Fatherland - The Martyrdom of a $100 \%$ Disabled War Victim', a KPD columnist detailed the tragic story of a nameless family in which the 'severely traumatized father' was completely unable to earn a living while his wife and daughter cared for his various nervous disorders until they were unable to pay the rent. Doctors allegedly ordered the neurotic father to be placed in a strait-jacket and forcibly removed from his family, which was then compelled to live in poor houses and barns. ${ }^{68}$ Another story told of a nameless mentally-ill veteran who shot himself, leaving a note: 'I shoot myself on my mother's grave, I am a poor, sick man. I can no longer live because I have lost my pension. ${ }^{69}$ In these articles that appeared during the Great Depression, there was no longer the earlier prescription for regeneration through active participation in the revolution. Though the Bund sympathized with these men, these veterans were portrayed as pathetic martyrs, unable to rehabilitate their health or re-assimilate into the community. Until the end of the capitalist health-care system, it was implied, these men were doomed to remain mentally ill, unable to provide for their families, adjust to the demands of work or overcome their traumatic memories of the war.

The KPD found in the treatment of psychologically-disabled veterans useful proof that widespread neuroses existed in the middle classes. However, war neurotics appeared as little more than victims, two-dimensional and without a voice of their own, in publications controlled by the KPD leadership. Communist portrayals of mentally-disabled veterans as martyrs of the capitalist state actually came to resemble images of 'pension neurotics' and 'hysterics' generated by the state's psychiatrists. Men who ten years after the war still displayed symptoms of psychological wounds and depended on the welfare

67 BA Berlin. Reichspressearchiv. R8034/2326. 'Der Fall Franzke-Rudolph vor dem Stadtparlament - Hinter den Kulissen der städtischen Kriegsbeschädigten-Fürsorge’, Berliner Lokale Anzeiger, no. 423, 9 September 1921.

68 'Der Dank des Vaterlandes!' - Das Martyrium eines 100\% Kriegsbeschädigten', Internationaler Bund, no. 3 (March 1932).

69 'Selbstmord', Internationaler Bund, no. 2 (February 1930). 
system, the Bund suggested, had lost their will to heal and their ability to be productive members of society. In the ranks of the radical working-class movement, 'hysterical' men thus had few options for declaring equal rights until the awaited moment when the existing power structure was transformed by revolution.

Social Democratic war victims' representatives, in contrast, assured their constituents that by working from within republican institutions, a wide set of social groups could recover from psychological wounds and attain war victims' status. However, shrinking economic resources made it impossible to fulfil these promises, and the SPD became more radical in asserting its argument that class interests dominated war victims' politics. With continuing cuts in the pension budget during the Great Depression, Social Democrats grew more convinced that the interests of different groups traumatized by the war could not be bridged. The public did not relate to war neurotics as a unique group with whom civilians shared the common traumatic experience of total war, but rather these men were widely seen as inherently deviant, undeserving of war victims' status. Though Social Democrats were unable to save mentallydisabled veterans from the first round of major pension cuts, the war neurosis debate provided them with a discourse to explain the psychological basis for these pension battles and class conflict in general. Social Democrats argued that while the working classes directly confronted Germany's traumatic past and healed their neuroses through the community of Social Democratic politics, the nation's middle classes repressed their traumatic memories of the war. War victims and their representatives insisted that where psychiatrists had failed, Social Democracy could heal mental wounds. However, working-class war victims observed, they could not help traumatized middle-class Germans who lacked the will to heal their memories of the war.

Disagreement over the origins of Germany's trauma lay at the heart of this debate over which social groups experienced the deepest neuroses. War victims and their representatives on the political left argued that until the nation recognized the war, and not the 1918 revolution, as the source of Germany's psychological crisis, there would be no chance of healing. The great 'psychosis' of the middle classes, both the SPD and the KPD argued, was their denial of the psychological damage caused by modern industrial warfare. The notion that the November revolution and democratic change was Germany's most traumatic event gained wider currency among middle-class groups traumatized by inflation, social levelling and economic dislocation, leading these groups to identify with the National Socialist interpretation of the war, defeat and revolution.

Jason Crouthamel is currently a Visiting Assistant Professor at Grand Valley State University, Grand Rapids, Michigan. He is working on a book entitled Invisible Traumas: Psychological Wounds, The First World War and German Society, 1914-45. 